\title{
Case study: project start-up for thickened graphite tailings, storage and water recovery strategies
}

\author{
A Chafy Syrah Resources Lda, Mozambique \\ M Tidswell Syrah Resources Lda, Mozambique \\ C Lane Land \& Marine Geological Services Pty Ltd, Australia
}

\begin{abstract}
This paper presents an overview of the tailings management and water recovery strategies that are proposed for the thickened tailings of the Balama graphite project, in northern Mozambique.

Graphite processing operations are rare globally, but tailings management is a challenge that almost all mining companies are facing. Water reuse is intrinsically connected to tailings management. Syrah Resources Ltd (the company) is a company starting a graphite mining and processing operation located in a remote area in the northern region of Mozambique. A region with enormous challenges ranging from sourcing qualified local manpower to infrastructure and logistics for supporting the project.

The biggest challenge is to maximise the lifetime of the tailings storage facility (TSF) and recycle more than $85 \%$ of water to minimise the freshwater intake and usage.

At the time of writing, the project was in the last steps of construction and is progressing through the commissioning phase. The company, in compliance with environmental and low-cost production requirements, has designed an interesting strategy for tailings thickening and water reuse.
\end{abstract}

Keywords: Balama, graphite, tailings, water

\section{Introduction}

Mozambique gained its independence from the Portuguese in 1975 which lead to a protracted fifteen year civil war lasting until 1992. Two years later, Mozambique held its first multi-party elections and has remained a republic ever since. The country has maintained political stability and is now one of the fastest growing economies in Africa. Although a great portion of the country's economy is based largely on agriculture, other industries such as aluminium and petroleum production, chemical manufacturing and tourism are growing. The mining industry has been growing at an exponential rate in recent years, pushed by the discovery of mineral resources such as coal, natural gas and graphite.

Graphite at the Balama site was first documented in 1893 by John H Furman, a geologist and engineer working for the Nyassa Company. The Balama project is situated in the Cabo Delgado province, in the district of Namuno, northern Mozambique, some $265 \mathrm{~km}$ west of the port town of Pemba (Figure 1). The climate is tropical savanna, with a wet season occurring during the summer months, dry winters and annual average evaporation significantly exceeding annual average rainfall.

Twigg Exploration and Mining Lda (a wholly owned subsidiary of Syrah Resources Ltd), is a Mozambican company that owned a license to investigate the Balama project site since 2010 with the main objective of searching for uranium. However, graphite was the predominant resource found. Syrah Resources Ltd carried out additional prospecting and site investigation with increased focus on the graphite and vanadium deposits at the site. 


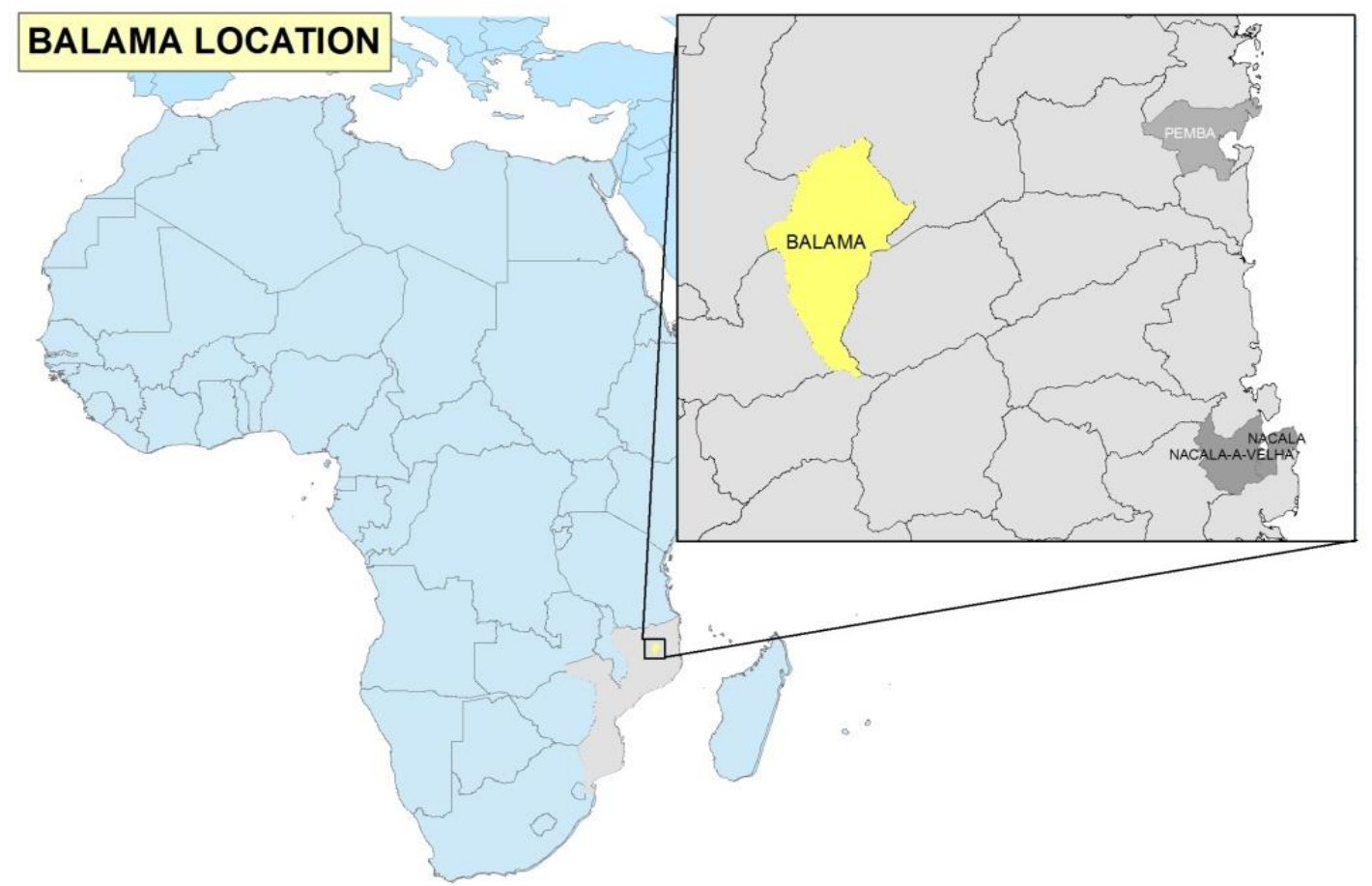

Figure 1 Location of Balama graphite mine owned by Syrah Resources

Project site development has progressed steadily since 2013, and by 2015 the major geological and financial evaluations had been completed and approvals obtained to start construction, mining and operations. Construction works commenced in late 2015 and commissioning of the process plant started in the summer of 2017.

\section{$2 \quad$ Project background}

Balama is located within the Cabo Delgado province in the district of Namuno in northern Mozambique. The project is approximately $265 \mathrm{~km}$ by road west of the port town of Pemba (Figure 1).

The Syrah Resources Ltd. Balama graphite project (Balama) is to comprise of an open pit mining operation consisting of two pits, a tailings storage facility (TSF), a process plant, an accommodation village and other minor infrastructure. The process plant is designed to treat ore at a rate of $2 \mathrm{M}$ tpa over an anticipated mine life of 40 years.

As reuse of water is essential to sustain the operation, the process plant is a closed circuit with only two opportunities for loss of water from the system. The first possible loss of water can occur during tailings transport via the pipeline that extends from the thickener to the TSF. Tailings coming from the thickener underflow pumps are expected to be discharged as $50 \%$ solids $/ 50 \%$ water slurry by weight. The tailings feed will be flocculated and densified in the thickener to minimise the volume of water that will be sent with the tailings to the TSF and to achieve the desired tailings thickening. In the discharge, a settled density of 1.20 to $1.30 \mathrm{t} / \mathrm{m}^{3}$ is expected, and in the TSF the residual moisture content, if the tailings are saturated, is 47.5 and $40 \%$ respectively. The second would be in the form of a small amount of water remaining in the product as it is dried at the tail end of the process. This moisture content could be up to $12 \%$ by weight of the final produced graphite.

Graphite tailings behaviour studies were completed to evaluate the amount of water that can be removed from the raw tailings and what the best way of achieving such dewatering would be. 
The TSF is to be located within an area north of the open pits, the process plant and the western most waste rock dumps. The chosen TSF site was identified in earlier phases of the project as being the preferred TSF location due to the absence of mineralisation, and the absence of any villages/dwellings within the proposed footprint. The location is also favourable given its proximity to the process plant. The total TSF comprises of five cells that will be constructed according to the tailings production ramp-up (Advisian 2016d).

\section{Regional and local geology}

The geology of northern Mozambique consists of Precambrian sedimentary rocks flanked by Jurassic to Neogene sediments of the Rovuma Basin (Danne 2014), located along the Indian Ocean coast and to the west by the Maniamba Graben which is filled with Permo Jurassic Karoo sediments (Figure 2).

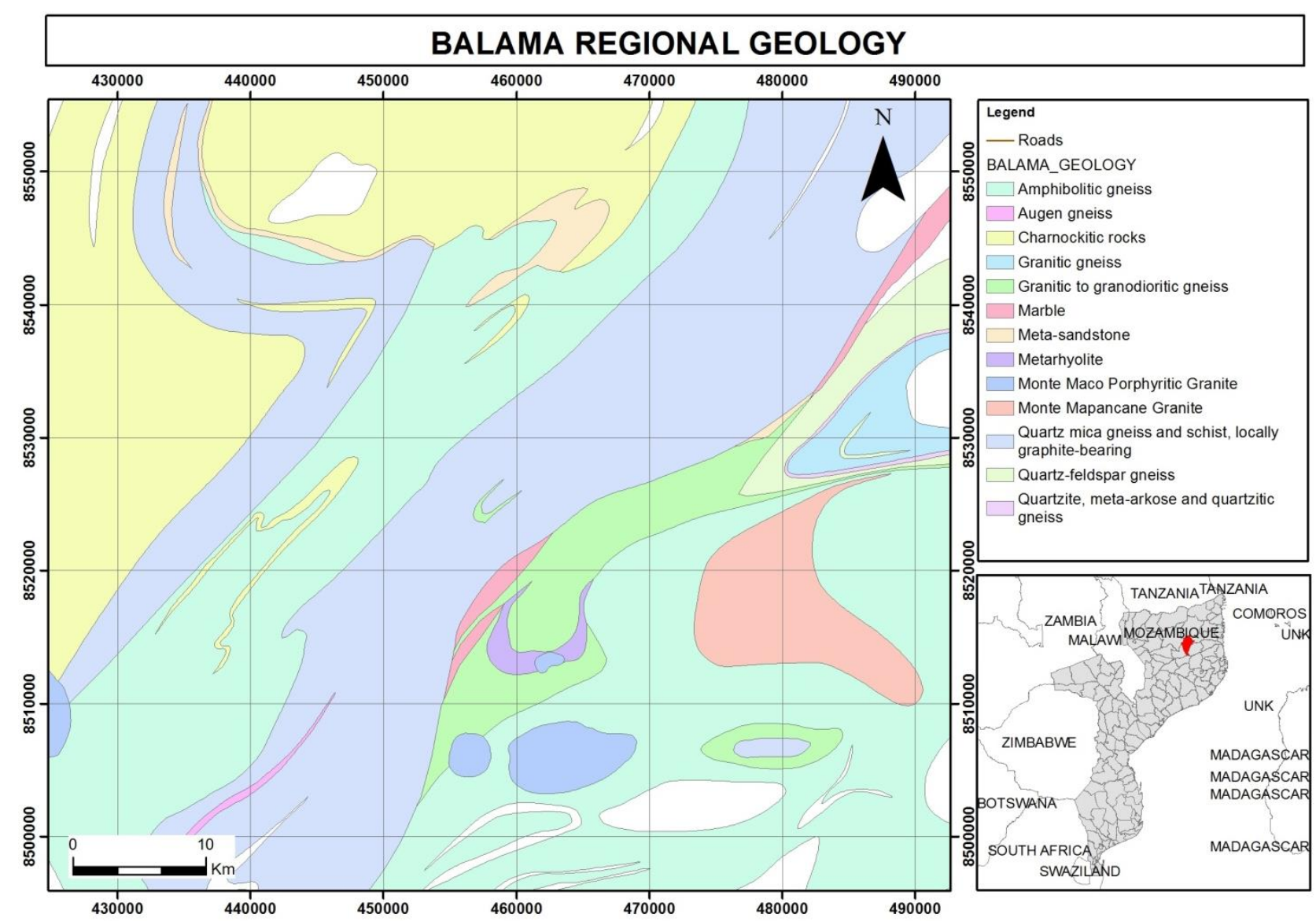

Figure 2 Regional geological map covering Balama area, highlighted

Balama is located within the Xixano complex which has amphibolite facies metamorphism dated at $735 \pm 4 \mathrm{M}$ years. It is the westernmost complex associated with the Cabo Delgado Nappe Complex (CDNC). Balama West is located at $13.326795^{\circ} \mathrm{S}, 38.657027^{\circ} \mathrm{E}$ and is hosted by a metasedimentary package of graphitic schists and gneisses with vanadiferous mineral phases indicated by green-coloured minerals visible in hand samples and under the microscope. Balama West is estimated to have approximately $170 \mathrm{Mt}$ of resources comprised of $18.96 \%$ total graphitic carbon (TGC) and $0.43 \%$ vanadium pentoxide $\left(\mathrm{V}_{2} \mathrm{O}_{5}\right)$. This estimate uses a $13 \%$ TGC cutoff, and is part of a larger regional JORC Code Inferred Resource of $1.15 \mathrm{~B}$ t estimated using a 10.2\% TGC cutoff. The vanadium pentoxide cutoff grade is $0.23 \%$ with a cutoff grade of $5 \% \mathrm{TGC}$. This makes the Balama deposit one of the largest high-grade graphite deposits in the world (Danne 2014). 


\section{$4 \quad$ Material and methods}

The authors of this paper used material previously gathered by Syrah Resources Lda during the exploration, feasibility study, constructions and commissioning phases of the project. Referenced sources include reports from contractors and service providers that are stored in the Syrah Resources information warehouse. Other sources cited are noted in the references section.

Laboratory analyses and field observations during commissioning are also part of the information that is analysed and presented in this paper.

\section{$5 \quad$ Balama graphite tailings properties}

\subsection{Geotechnical properties}

Two samples of the proposed tailings from the process plant were provided to the Brisbane laboratory of TriLab Pty Ltd for geotechnical testing. The samples were provided to TriLab Pty Ltd by SGS Canada Inc., Lakefield, Ontario, Canada, and comprised an optimised composite from the flotation testwork (Outotec 2015).

The results of the particle size distribution (PSD) testing indicate that the tailings can be classified a sandy Silt, with Unified Soil Classification (USC) group symbol ML (Outotec 2015).

Direct shear and triaxial tests were undertaken on remoulded samples compacted to $95 \%$ standard maximum dry density (SMDD) at optimum moisture content (OMC) (Outotec 2015).

Air drying and settling tests conducted under drained and undrained conditions indicate that the tailings will settle out of suspension rapidly.

The objective of the undrained settling tests was to monitor tailings settlement and clarity of supernatant water. Such conditions may exist at a point under the tailings beach without underdrainage to facilitate removal of supernatant water. By monitoring the height of the solids and the achieved dry density over time, the rate at which water is released from deposited tailings was assessed.

\subsection{Geochemical properties}

\subsubsection{Acid-formation potential classification}

Geochemically based parameters and acid-formation potential (AFP) classification criteria described in this section apply equally to samples of mine waste, low-grade ore, and process tailings solids. The generic descriptor 'test-sample' is used. Table 1 shows the acid-base-analysis (ABA) and net-acid-generation (NAG) results for tailings solid samples (Graeme Campbell and Associates Pty Ltd 2016). The following abbreviations are used in Table 1:

- Maximum-potential-acidity (MPA).

- Net-acid-producing-potential (NAPP).

- Potentially acid forming (PAF).

- Not acid forming (NAF).

- Acid-neutralising capacity (ANC). 
Table 1 Acid-base-analysis (ABA) and net-acid-generation (NAG) results for tailings solids samples

\begin{tabular}{|c|c|c|c|c|}
\hline & & & Low-S & High-S \\
\hline \multicolumn{3}{|l|}{ Total-S (\%) } & 0.05 & 1.09 (1.10) \\
\hline \multicolumn{3}{|l|}{$\mathrm{SO}_{4}-\mathrm{S}-\left[\mathrm{Na}_{2} \mathrm{CO}_{3}\right](\%)$} & 0.03 & $0.08(0.09)$ \\
\hline \multicolumn{3}{|l|}{$\mathrm{SO}_{4}-\mathrm{S}-[\mathrm{HCl}](\%)$} & 0.04 & $0.09(0.11)$ \\
\hline \multirow{2}{*}{ Total-S -SO ${ }_{4}-\mathrm{S}(\%)$} & \multicolumn{2}{|c|}{$\mathrm{NaCO}_{3}$} & 0.02 & 1.02 \\
\hline & \multicolumn{2}{|l|}{$\mathrm{HCl}$} & 0.01 & 1.01 \\
\hline \multicolumn{3}{|l|}{$\mathrm{Cr}(\mathrm{II})$ red-S (\%) } & 0.008 & 0.83 \\
\hline \multicolumn{3}{|l|}{ Total-C (\%) } & 0.57 & $0.58(0.58)$ \\
\hline \multirow{6}{*}{$\mathrm{Kg} \mathrm{H}_{2} \mathrm{SO}_{4} /$ tonne } & \multicolumn{2}{|c|}{$\mathrm{CO}_{3}-\mathrm{C}(\%)$} & 0.03 & $0.18(0.19)$ \\
\hline & \multicolumn{2}{|c|}{ Bulk-ANC } & 2 & $17(18)$ \\
\hline & \multicolumn{2}{|c|}{ Carb-ANC } & 2.5 & 15 \\
\hline & \multicolumn{2}{|l|}{ NAPP } & -1.8 & 8.4 \\
\hline & \multirow{2}{*}{ NAG } & $\mathrm{pH}=4.5$ & $<0.5(<0.5)$ & $7(6)$ \\
\hline & & $\mathrm{pH}=7.0$ & $<0.5(<0.5)$ & $15(14)$ \\
\hline \multicolumn{3}{|l|}{ NAG-pH } & $6.8(6.7)$ & $3(3.1)$ \\
\hline \multicolumn{3}{|l|}{ AFP category } & NAF & PAF \\
\hline
\end{tabular}

\section{Balama graphite mine tailings thickening process}

Graphite concentrate and tailings production generally involve crushing, milling and grinding, flotation, thickening, filtration, drying and finally screening and bagging of the final product. The type of thickener used at the site is a cylindrical continuous thickener, with mechanical sludge-raking arms.

Achieving an underflow density of $50 \%$ solids $(w / w)$ is controlled by monitoring and measuring bed mass, hydrostatic pressure, the solids level and tailings pumping speed. The signal from the bed mass transmitter is compared to a set point, and the speed of the underflow discharge pumps are varied accordingly.

The bed level in the thickener is impacted by the addition of flocculent. The amount of flocculants added is controlled by changing the speed of the flocculent pump motor. Overflow quality is monitored with a turbidity meter or with a timed settling test using a measuring cylinder. The slurry density is automatically measured by a density information controller (DIC) and can be manually assessed by taking a sample and measuring it using a Marcy Scale. The information captured through the automated DIC system feeds a control loop that tells the underflow pumps when to send the tailings to the TSF and when to put the thickener into recycle mode to thicken the tailings to the desired density prior to sending them for discharge at the TSF. This ensures that tailings that did not meet the required $50 \%$ slurry density is thickened prior to deposition.

Thickened graphite concentrate slurry is the underflow produced by the thickener and is pumped from the thickener to the TSF via a slurry pipeline. 


\subsection{Flocculants selection}

Based on the results from static cylinder tests, the flocculants selected for the dynamic testwork was BASF Magnafloc 155. Flocculants screening was conducted in $500 \mathrm{ml}$ static cylinder tests on $5 \%$ solids $(\mathrm{w} / \mathrm{w})$ raw tailings. Figure 3 shows the settling rates from the completed static cylinder tests (Graeme Campbell and Associates Pty Ltd 2016).

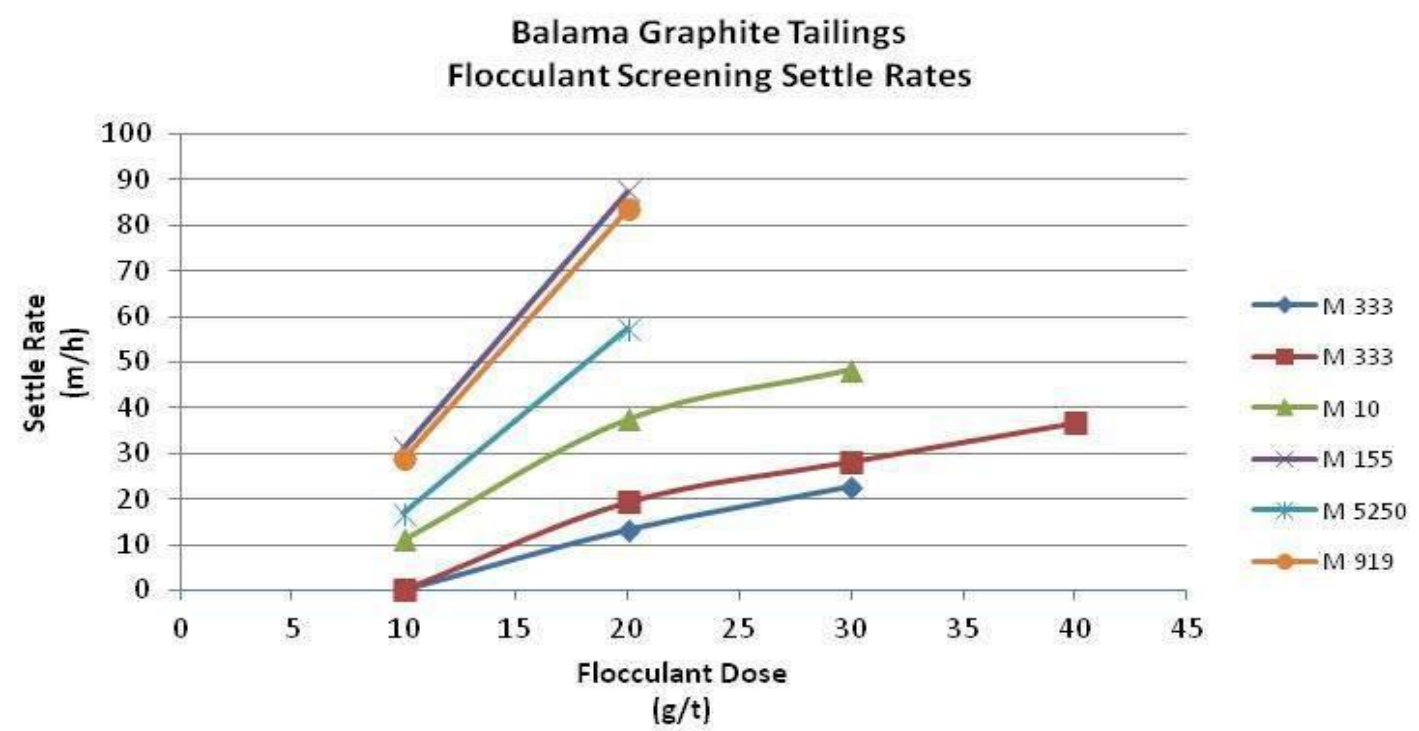

Figure 3 Balama graphite tailings settle rates at $5 \%$ solids $(w / w)$ in $500 \mathrm{ml}$ static cylinder tests

BASF Magnafloc 155 was selected for dynamic thickening testwork as it produced the lowest solids content supernatant and had a consistently fast settling flocculation at the lowest dose. It should be noted that statement of these results should not be viewed as an endorsement of any supplier named but rather a direct reporting of the findings of the completed test work (Graeme Campbell and Associates Pty Ltd 2016). Other products deemed to be equivalent may be used in the thickener.

\subsection{Balama tailings storage facility overview}

There are presently no specific regulatory requirements or guidelines for Mozambique which specify the design and operation of a TSF. In the absence of these guidelines, the design has been prepared in accordance with the Australian National Committee on Large Dams Guidelines on Tailings Dams (ANCOLD 2012), with reference given to the International Committee on Large Dams Bulletin 153: Sustainable Design and Post-Closure Performance of Tailings Dams (ICOLD 2013). In accordance with ANCOLD (2012), the TSF is classified as a High A Hazard Category TSF based on the facility having:

- A perimeter embankment crest level $<35 \mathrm{~m}$.

- Major severity level impact with $<20 \mathrm{~km}$ impact area, impact duration $<20$ years, dislocation of $>1,000$ people for greater than one month, and a severe to crippling impact on the business.

- A population at risk (PAR) of between 100 and 1,000 persons. 
The final TSF will be comprised of a series of five cells (refer to Figure 4, the general arrangement of the cells) with the base of the facility and the upstream slopes of the starter embankments to be lined with a synthetic liner to reduce the potential for migration of contaminants from the tailings. The cross-section on Figure 4 shows the profile of the TSF starter embankments and the lining method (WorleyParsons 2016a). Cell 1 was to be constructed concurrently with the other mining infrastructure needed for operations start-up. Perimeter embankments will be progressively raised using the upstream method to provide tailings storage for the mine life (WorleyParsons 2016b). Around the TSF perimeter some boreholes are located to provide underground water quality and level (Australian Government 2016).

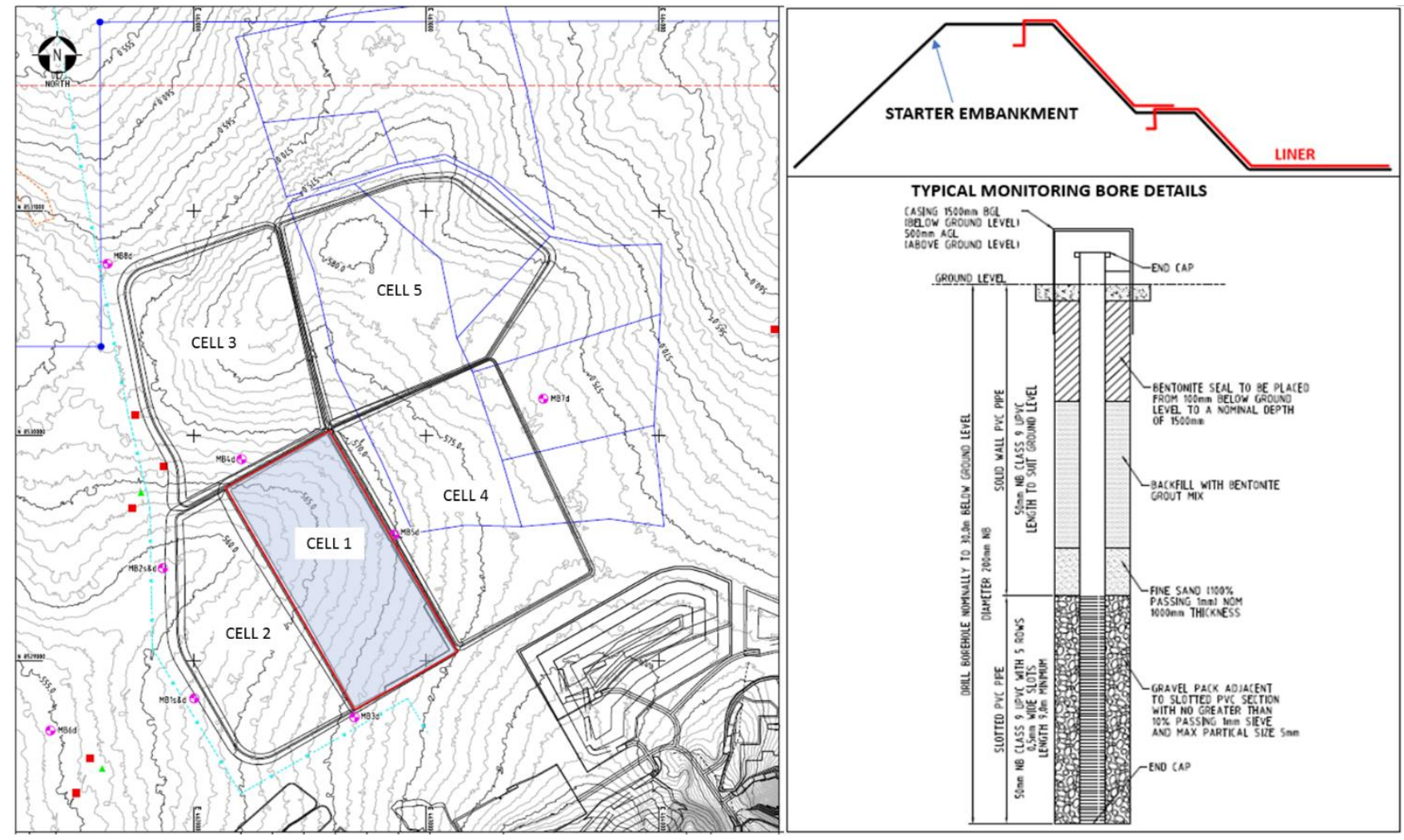

Figure 4 Tailings storage facility footprint and cells, highlighted Cell 1

The starter embankment of Cell 1 will have a storage capacity of $3.35 \mathrm{M} \mathrm{m}^{3}$ of tailings - enough to provide storage of the forecast tailings production during the first 2.1 years of the mine operation based on the mine plan (Advisian 2017). The plan was to start with the Cell 1, but because of construction delays and the need to have at least one cell ready at start-up, an alternative plan was proposed to subdivide Cell 1 into two (Cell $1 \mathrm{~A}$ and Cell 1B) and prioritise construction of Cell 1A.

By October 2017, Cell 1A was ready to receive tailings as construction was complete including installation of the water reclaim infrastructure. Construction of Cell $1 \mathrm{~B}$ to complete Cell 1 is anticipated to proceed as shown in Figures 5(a) and (b), respectively. 


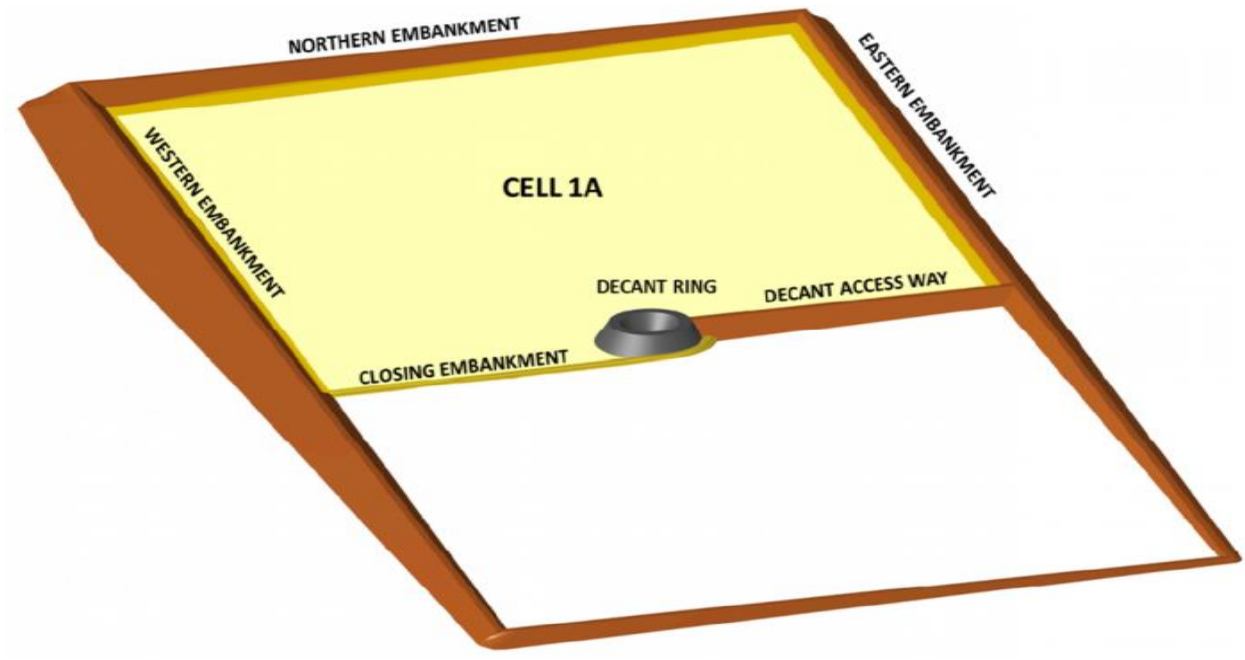

(a)

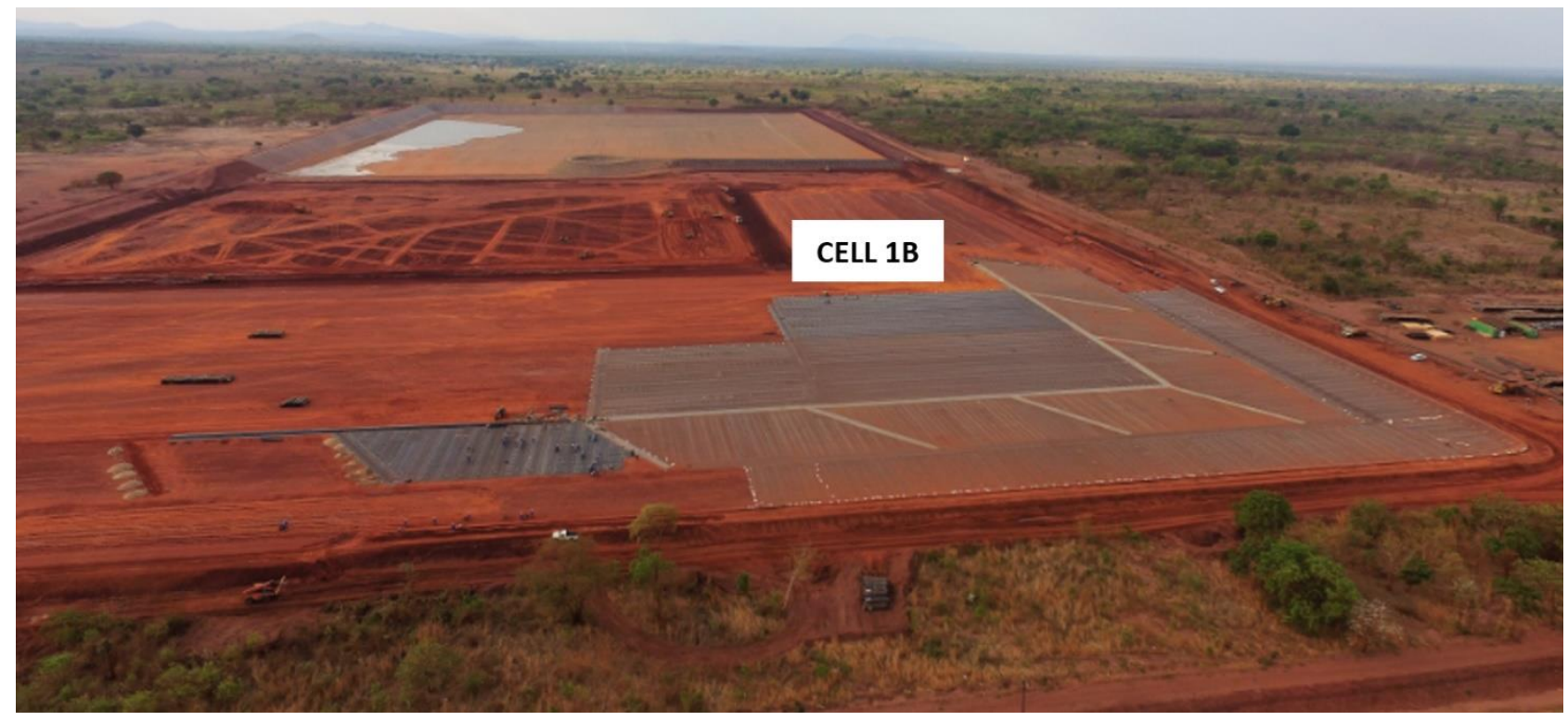

(b)

Figure 5 (a) Cell 1 schematic representation; and, (b) Cell 1 updated picture (highlight for the Cell $1 \mathrm{~B}$ lining progress)

\section{$7 \quad$ Tailings deposition strategy}

The initial tailings deposition plan was developed for Cell $1 \mathrm{~A}$ since that was the first completed and commissioned tailings impoundment at the project site. Cell $1 \mathrm{~A}$ provides approximately $360,000 \mathrm{~m}^{3}$ of tailings storage capacity which is enough to store the first nine months of tailings generation (Figure 6). During this period, Cell 1B will be constructed to complete Cell 1 (Advisian 2016a).

Including TSF Cell 1B, the total capacity of Cell 1 increases to $3.35 \mathrm{M} \mathrm{m}^{3}$ and by effectively managing the water contained in the TSF, the life of Cell 1 can be expanded to two years and seven months (Figure 7), thereby adding almost six months of tailings storage capacity.

Water recovery rates include rainfall events based on historical precipitation data from the Montepuez city climate base and the rain station located at the Syrah camp site in Balama (Advisian 2016b). 


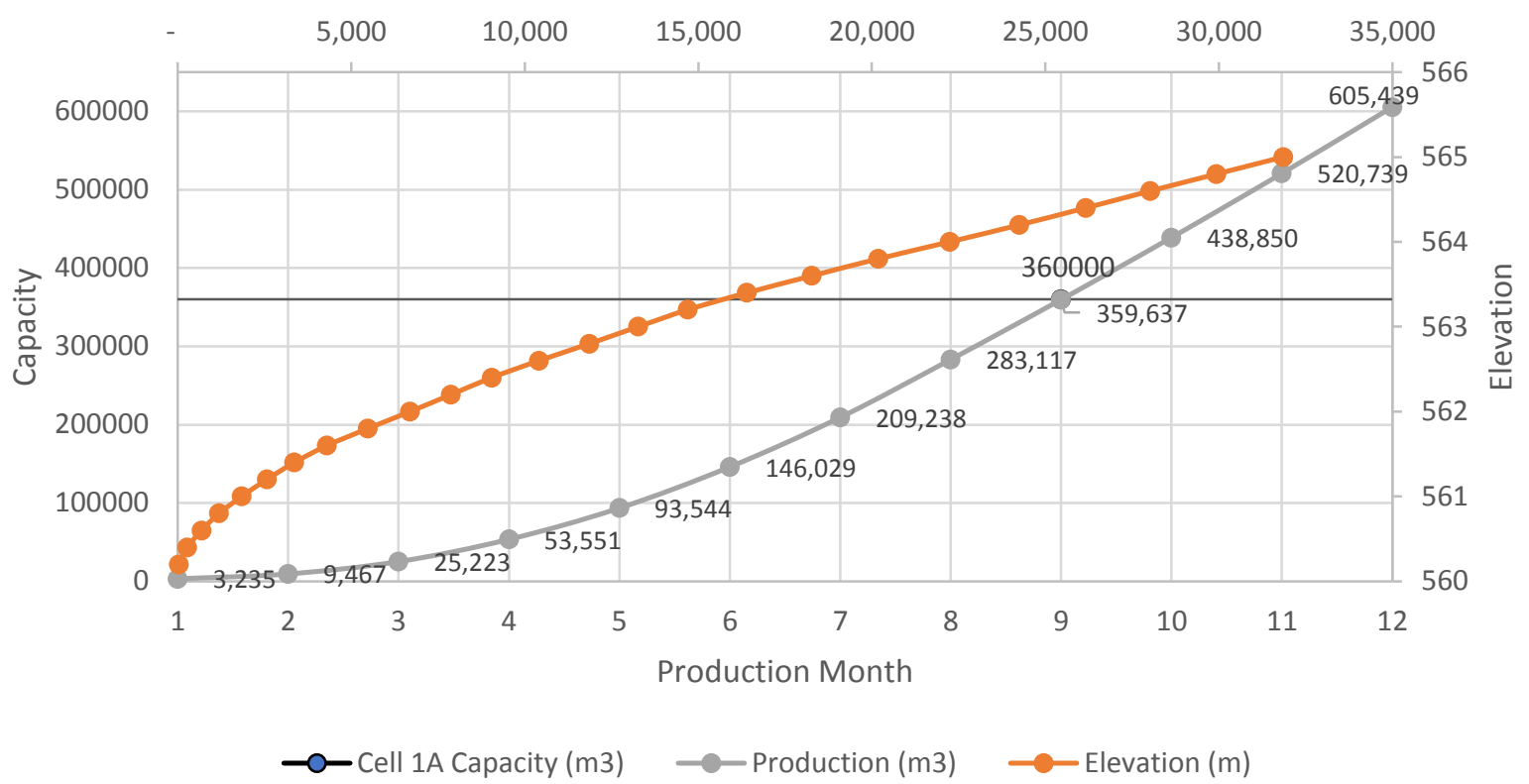

Figure 6 Cell 1A storage capacity

Based on this historical precipitation data and the mine plan, the volume of water expected to enter the TSF was calculated as well as the volume of water possible to be reclaimed from the TSF producing the Cell 1 storage utilisation curve (Figure 7).

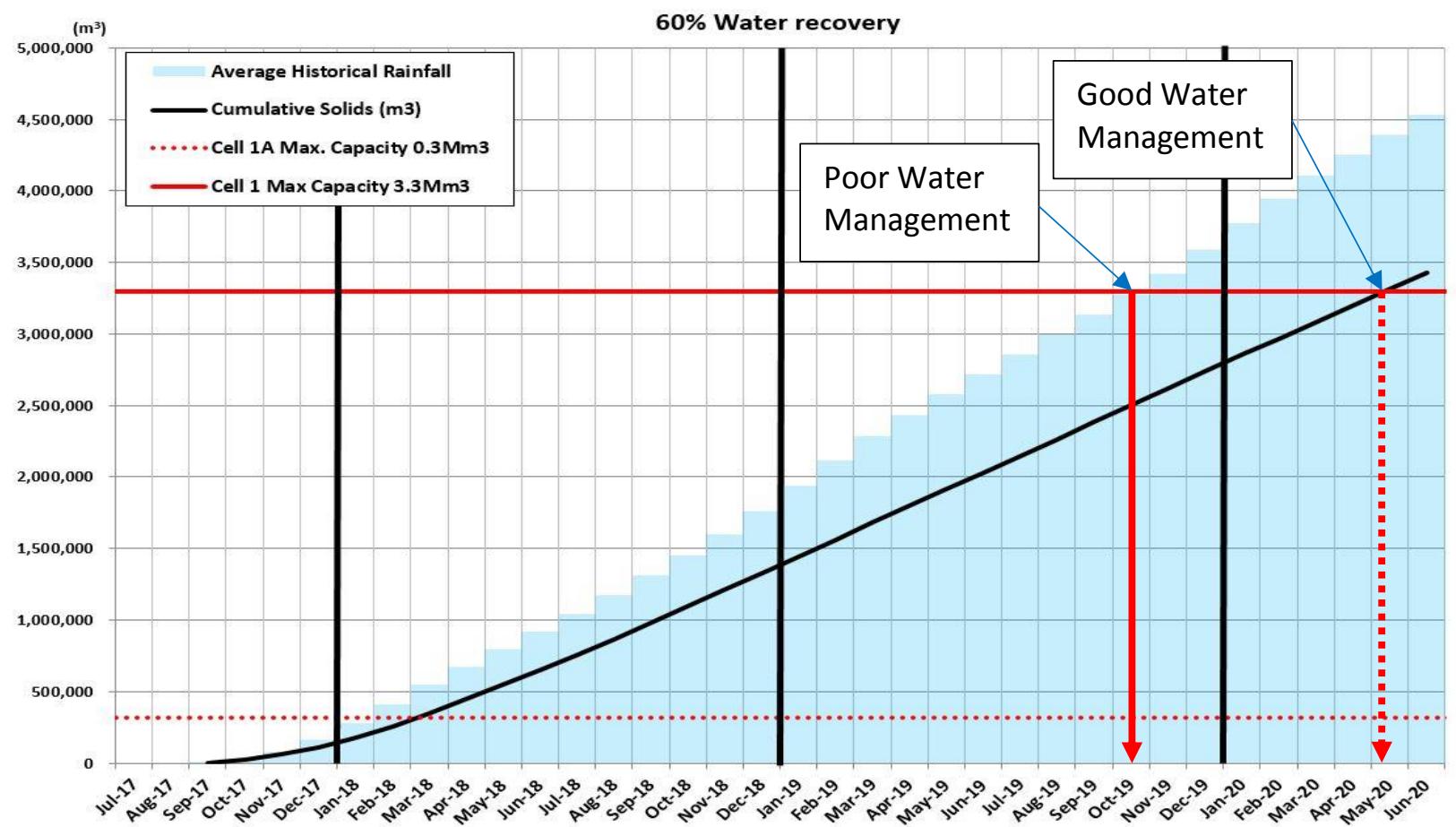

Figure 7 Cell 1 ramp-up deposition plan and water management overview 


\subsection{Cell 1 water reclaim strategy}

Tailings storage facility cells are usually designed with the objective of recovering water for the process plant to reuse. To support this objective at the Balama project, Cell 1A TSF is completely underlain by an underdrainage channel system composed of filter rock. The decant structure, referred to in the project as the decant rock ring (DRR), was constructed from a ring of rock where supernatant water can be collected and ultimately returned to the process dam (Figure 5(a)) (Advisian 2016b).

At project start-up, it is expected that tailings will be deposited initially on the liner located on the upstream face of the starter dam and then flow through the underdrainage channels which will convey water to the lowest part of the tailings storage area. This will allow operations to start recovering water from the initial deposition stages during commissioning and early operations (Advisian 2016c).

By October 2017, the slotted pipes to be used for tailings deposition were installed with additional work required to connect the remaining tailings discharge line. This will be completed in advance of full commissioning and operation of the TSF.

The overall Cell 1 arrangement is shown in Figure 8, with the limits of Cell $1 \mathrm{~A}$ and underdrainage channels highlighted in red.

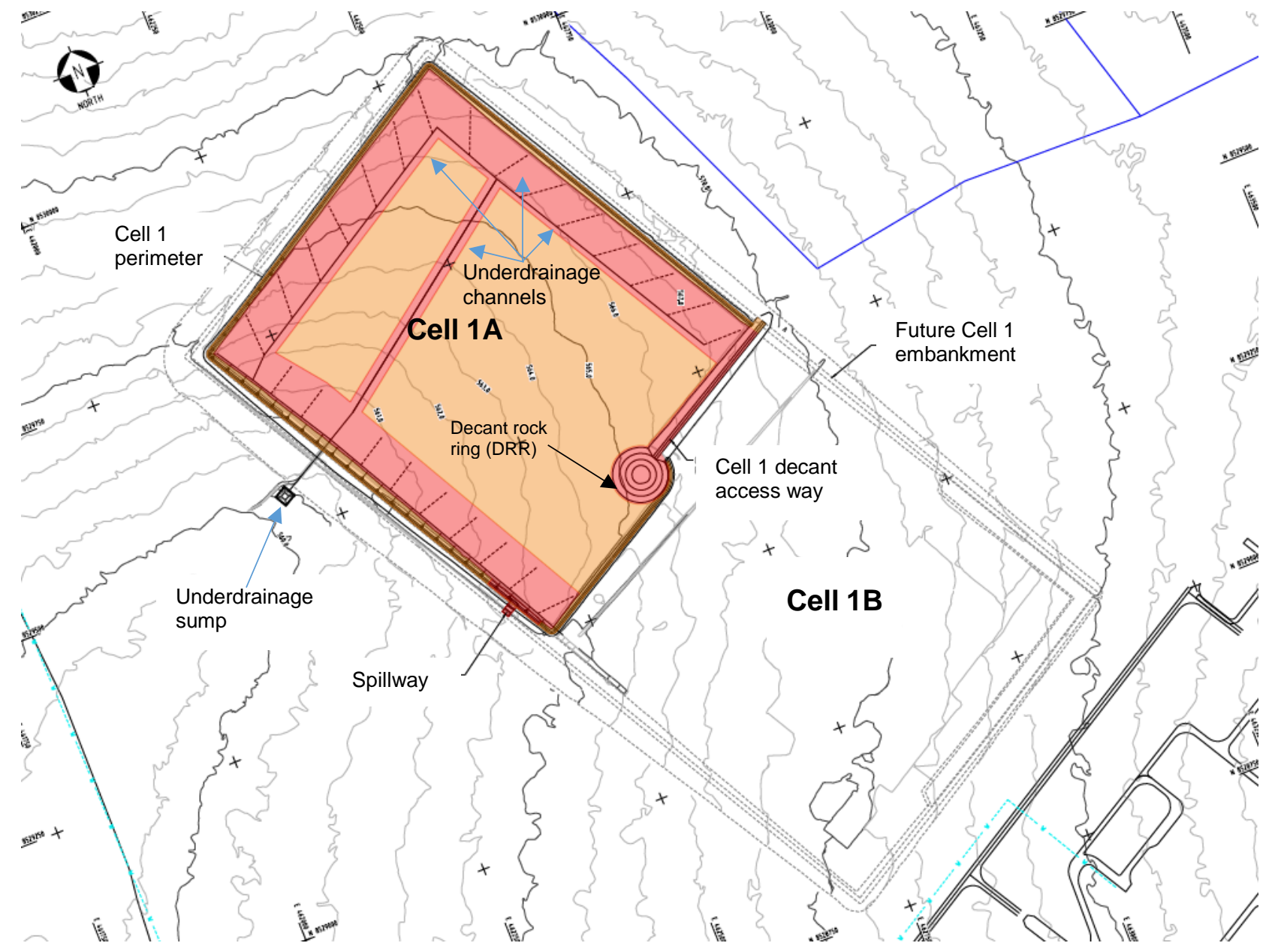

Figure 8 Cell 1A (part of Cell 1) complete and earthworks ongoing on Cell 1B

The underdrainage channels located on the northern perimeter of Cell $1 \mathrm{~A}$ collect water that flows from and through the deposited tails and conveys water to an underdrainage sump located on the western side of Cell $1 \mathrm{~A}$ (Figure 8). All water collected from this sump will be pumped back to the plant for reuse. When the effectiveness of the underdrainage system decreases in time as the deposited tailings consolidate, water from the sump will 
be returned to the TSF to increase the size of the supernatant lake so that water will flow to the DRR. From the DRR, the water will be pumped back to the process dam to be reused in the process plant.

Figures 9(a) through (d) show the deposition sequence and supernatant water movement to the DRR. On Figures 9(a) and (b), tailings deposition locations for the first nine months of operation are shown. Figures 9 (c) and (d) represent subsequent tailings deposition when tailings will also be deposited into Cell $1 \mathrm{~B}$ and ultimately discharged around the full perimeter of the completed Cell 1.

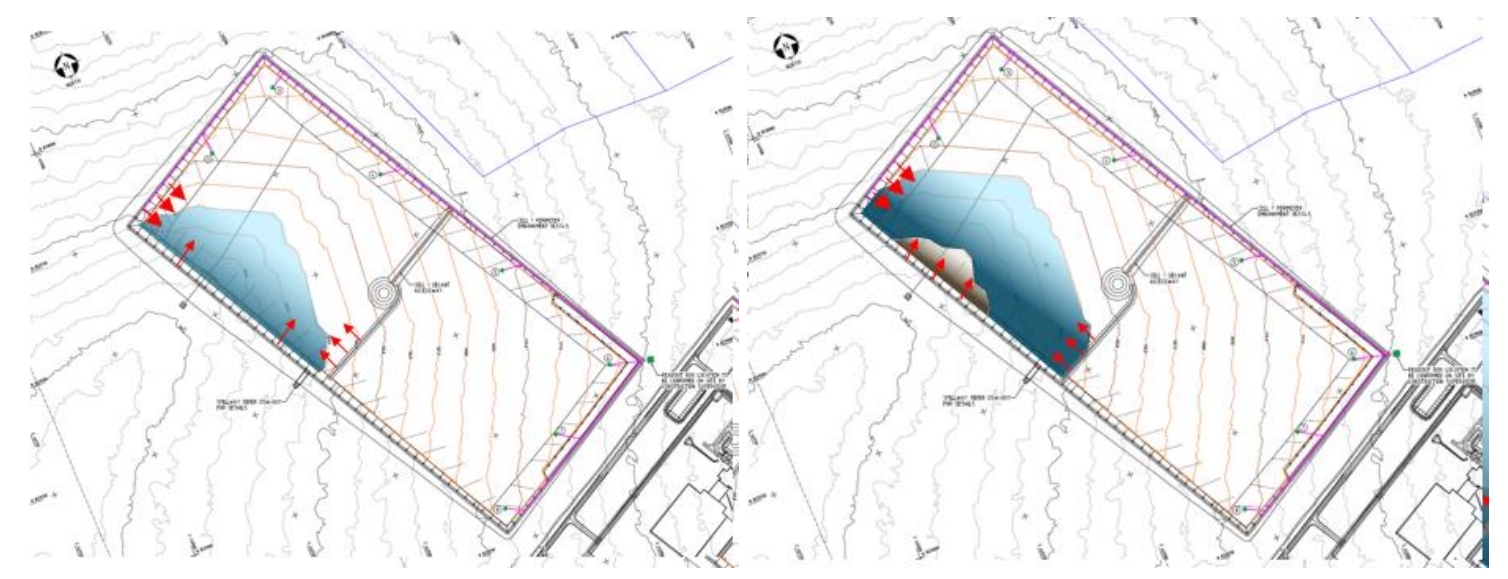

(a)

(b)

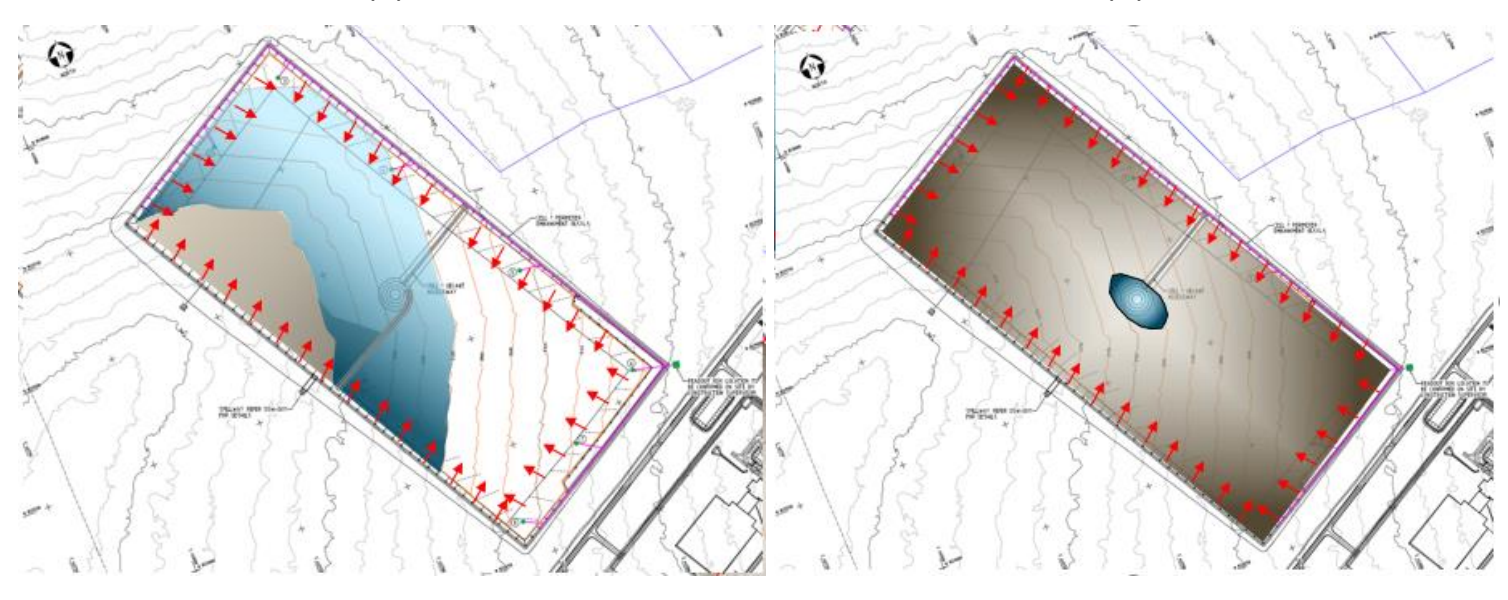

(c)

(d)

Figure 9 Tailings deposition strategy on Cell 1 showing the beach movement to the DRR

\section{Discussion}

As the tailings are classified as either potentially acid forming (PAF) or not acid forming (NAF), the upstream faces of the starter dams will be completely lined with a geosynthetic liner. Furthermore, tailings will be stored in each of the five TSF cells that will be built in sequence according to the mine plan.

According to Advisian (2016d), key points to note from the results of the undrained settling tests competed on tailings slurry with a slurry density of $50 \%$ solids (weight by weight, w/w), are:

- At discharge, the tailings have a deposited dry density of nominally $0.72 \mathrm{t} / \mathrm{m}^{3}$.

- After a period of 24 hours post deposition, the tailings dry density increases to $1.02 \mathrm{t} / \mathrm{m}^{3}$, allowing $37 \%$ of the water discharged to be available for recovery (or loss to evaporation).

- The dry density of the tailings peaks at $1.10 \mathrm{t} / \mathrm{m}^{3}$ after 47 hours, with a further marginal increase to $1,112 \mathrm{t} / \mathrm{m}^{3}$ achieved after an additional 24 hours ( 71 hours total). This allows for a total of $45 \%$ of the water discharged with the tailings slurry to be available for recovery (or lost to evaporation). 
The objective of the drained settling test was to monitor tailings settlement and to evaluate supernatant and underdrainage clarity. As with the undrained settling tests, by monitoring the height of the solids and the achieved dry density over time, an indication of the speed at which water is released from tailings solids could be assessed.

Tailings storage facility cell wall rising will be performed using the upstream method and will use consolidated tails located close to the cell walls to complete each lift. It is expected that the deposited tailings will achieve the desired dewatering and associated density characteristics since the underdrainage channels are distributed evenly across the TSF Cell 1 footprint which was designed to enable effective flow from the underside of the deposited tailings. Before deposited tailings are used for wall rising, geotechnical testing and TSF raise design evaluations will need to be performed.

Recovering $60 \%$ of water from the TSF increases the final dry density and ultimately optimises the life of the TSF.

During the first weeks of commissioning, it was possible to confirm some of the findings from the completed laboratory analyses. Installation of the geosynthetic liner is aiding recovery of water from the tails. Additionally, the density of the tails has been a very important part of this success. All tailings have been retained close to the slotted pipe discharge which has enabled the released water to run to the drain at the lowest point of the Cell 1A (Figure 10) where the underdrainage pipe is located and conveys water to the underdrainage sump through gravity flow.

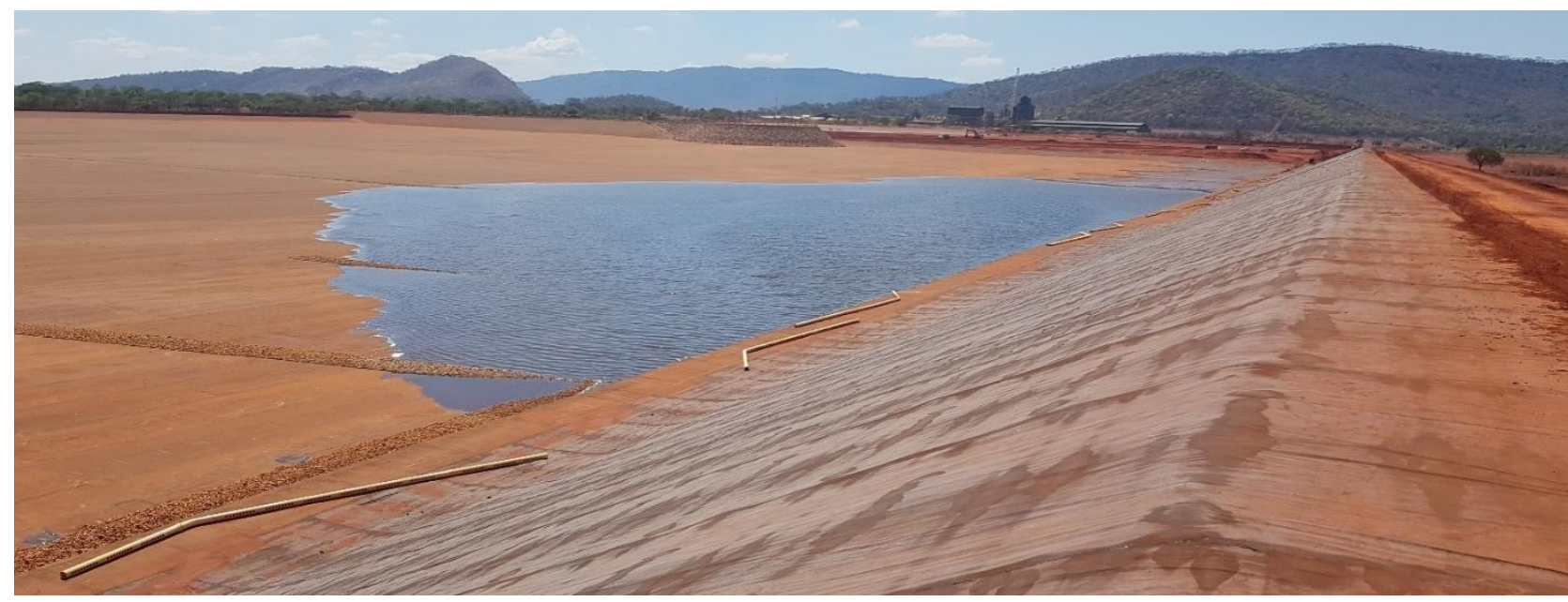

Figure 10 Deposition tails and clear separation of water to the lowest point of the dam

From the underdrainage sump, the water will be pumped back to the process dam for reuse. This runoff factor helps the thickening of the tails along the slotted pipe and wall areas as excess moisture is removed (Figure 11).

Once the tails are well compacted and controlled beaching takes effect through the effective management of deposition using the spigot deposition strategy, supernatant water will be directed towards the DRR to facilitate effective and efficient water return to the plant in the future. 


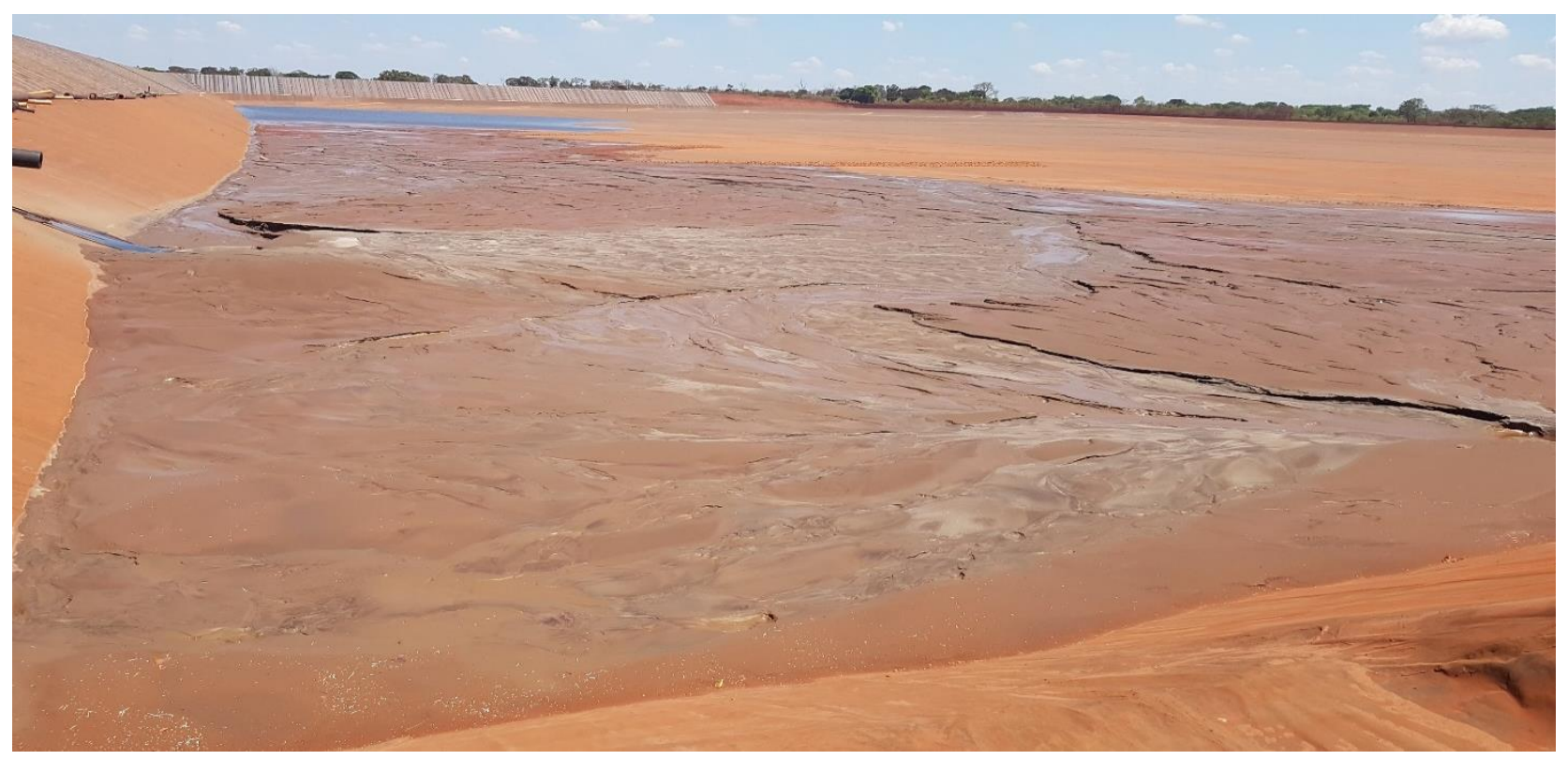

Figure 11 The start of beach formation and water separation from tails

\section{Conclusion}

Many factors can be found that can guide the thickening of tails during deposition into a TSF. In the case of the Balama graphite project, the slurry density is the key to successful utilisation of the TSF storage. Another determining factor is how fast the beach is formed and the volume of water reclaimed from the TSF and returned to the plant.

The geochemical characterisation of the tails considers that the PAF is high. To avoid soil and underground water contamination, the base of the facility and the upstream slopes of the starter embankments are to be lined with a synthetic liner to reduce the potential for migration of contaminants from the site as Cell 1 is already. The followed embankment lifts will be upstream so that the latter tails will be contained by the starter embankment. If water management in the TSF is completed according to the proposed plan then the thickened tails will likely meet their geotechnical design specifications and will be able to be used as embankment lift construction material.

The underdrainage sump will be useful to recover water from tails during the initial nine month operating period. Once the tails start densifying, it is anticipated that underdrainage flow will decrease. The flow into the underdrainage sump will continue to be monitored and the water level in the sump will be pumped to the top of the TSF to help direct supernatant water towards the DRR for recovery and reuse in the plant.

When Cell $1 \mathrm{~B}$ is commissioned and starts to operate, tailings deposition will be managed around the overall Cell 1 perimeter to control and direct above water beach development and to push water towards the DRR.

As of October 2017, it was still too early to conclude that the settling time in the TSF is consistent with the design because the actual deposition is happening subaerial and the water is far from the discharge point.

\section{References}

Advisian 2016a, Liner Construction Scope of Work, Tailings Storage Facility 1, Balama Graphite Project, Advisian, Melbourne.

Advisian 2016b, Balama Graphite Mine: Water Management Plan, doc 201310-08515-HY-REP-002, Advisian, Perth.

Advisian 2016c, 201310-08515- Operations Manual: Tailings Storage Facility Cell 1, Balama Graphite Project, Balama, Mozambique, Advisian, Perth.

Advisian 2016d, Tailings Storage Facility Design Report, Balama Graphite Project, Mozambique, Advisian, Melbourne.

Advisian 2017, Tailings Storage Facility, Cell 1A - Construction Report, Balama Graphite Project, doc 201310-08515-201310-08515SS-REP-0002, Advisian, Perth.

ANCOLD 2012, Guidelines on Tailings Dams - Planning, Design, Construction, Operation and Closure, ANCOLD, Hobart. 
Australian Government 2016, Tailings Management - Leading Practice Sustainable Development Program for the Mining Industry, https://industry.gov.au/resource/Documents/LPSDP/LPSDP-TailingsHandbook.pdf

Danne, D 2014, Origin and Control of Graphite- and Vanadium-Rich Horizons at Balama West, Mozambique, East Africa, honours in geology, Monash University, Melbourne.

Graeme Campbell and Associates Pty Ltd, 2016, Geochemical Characterisation of Process-tailings Samples (Balama West Ativa Zone), Implications for Design of Tailings-storage Facility and Medium-Grade Management, job no. 1502, Graeme Campbell and Associates Pty Ltd, Bridgetown.

ICOLD 2013, Bulletin 153: Sustainable Design and Post-closure Performance of Tailings Dams, ICOLD, Paris.

Outotec 2015, Thickening Test Report, Case S2680TA, Balama, Mozambique, Outotec, Perth.

WorleyParsons 2016a, Tailings Storage Facility Design Report, Balama Graphite Project, Mozambique, document 201310-08515-SSREP-0001, revision 1, WorleyParsons, Sydney.

WorleyParsons 2016b, Water Management Plan, Balama Graphite Project, Mozambique, document 201310-08515-HY-REP-002, revision 1, WorleyParsons, Sydney. 